\title{
Stock Market Activities and Economic Growth in Nigeria: A Cointegration Approach
}

\author{
Ashamu Sikiru O. $P h D$ \\ Department of Banking and Finance \\ Faculty of Management Sciences \\ Lagos State University, Ojo, Nigeria \\ E-mail: soyerinde2012@gmail.com \\ Soyebo Yusuf A. $P h D$ \\ Department of Banking and Finance \\ Faculty of Management Sciences \\ Lagos State University, Ojo, Nigeria \\ E-mail: yusuf.soyebo@lasu.edu.ng
}

\begin{abstract}
Stock markets have been the main catalyst of economic growth in most economies. However, there are mix results on the exact nature of the influence of key stock market variables on economic growth in developing economies. Thus, this study examined the effect of stock market measures on economic growth in Nigeria. This paper employed an ex-post facto research design using annualized data obtained from the Central Bank of Nigeria (CBN) Statistical Bulletin and Stock Exchange Fact books for the period 1985 to 2017 and they were analysed using the error correction estimate regression technique at $5 \%$ level of significance. The result ecm $(-\mathrm{I})$ is statistically sign and significant, stock market activities such as market capitalization $\left(\lambda_{1}=0.0386, \mathrm{p}>\right.$ 0.05), number of deals $\left(\lambda_{2}=0.0487, \mathrm{p}<0.05\right)$ and All share Index $\left(\lambda_{4}=0.092 \mathrm{I}, \mathrm{p}<0.05\right)$ have positive influence on economic growth, while volume of trading $\left(\lambda_{3}=-0.6110, p<0.05\right)$ has a negative effect on economic growth. These results suggested that all the specified variables except market capitalization have significant effect on economic growth in Nigeria. The study concluded that stock market activities influence the economic growth in Nigeria. Therefore, it is recommended that investors should take the advantage of the numerous opportunities offered by the stock market while market makers and regulators should continue to operate according to best market practices in order to ensure confidence and continuous patronage by various economic agents.
\end{abstract}

Keywords: Stock Market, Market Capitalization, Economic Growth, Investors, Cointegration.

JEL Classification: GI2, G2I.

\section{Introduction}

Generally, the stock market provides the mechanism for assembly and allocation of medium and long-term financial resources between economic units in order to facilitate optimum resource distribution, wealth creation and economic growth. Stock market enables financial intermediation as they ensure regular trading in listed financial securities and ensure that quoted firms have adequate access to capital. Thus, a functional stock market supports financial system through the provision of alternative finance to business and investment outlet to investment (Pan \& Mishra, 2016).

Beck and Levine (200I) reported that a well-functioning stock market nurtures growth and profit incentives and prompt in risk management as a developed stock market provide liquidity that lowers the cost of capital essential for development, particularly in less developed countries that generate insufficient domestic savings (Bencivenga, Smith \& Stair I996).

However, in most emerging economies, financial turnover is slow due to long gestation period required in the ownership transfer process. Thus, the transaction costs on the stock market activities often influenced production decision and the growth rate in the economy. Similarly, transaction costs tend to fall on the stock market as it develops, the liquidity risk decreases and more illiquid projects can be funded. The link between stock market activities and economic growth in Nigeria has been puzzling due to the peculiar nature of stock market activities as well as the mix results turned in by various scholars due to the measurement of variables, data analysis techniques and scope of study.

Hence, the postulate that stock market activities influence economic growth in Nigeria requires further empirical consideration. This study assumes that there is no significant short and long-run relationship between stock market activities and 
economic growth in Nigeria. The remaining sections of the paper are structured as follows: next are the literature review, methods and materials, followed by results, discussion, recommendations and conclusion.

\section{Literature Review}

The economic growth of a nation represents the changes in the level of economic activities over a specific period and the stock market has the potentials of spurring economic growth via prompt resource allocation and distribution which result in higher economic activities (Popoola, 20I4). Thus, the role and consequence of an effective capital mobilization mechanism in the development of the economy has been observed in literature.

In developing and developed economies, several authors had reported their views on the influence of stock market on economic growth. For example, Osei (2005) examined the relationship between stock market development and economic growth in Ghana. The result revealed a unidirectional relationship from stock market performance to economic growth. Similarly, Enisan \& Olufisayo (2009) studied the influence of stock market performance on economic growth in selected Sub - Saharan Africa using the Autoregressive Distributed Lag on annual data such as market capitalization and GDP. The result revealed that stock market development has positive and significant long run influence on economic growth in Egypt. South Africa, Cote D’ Ivoire, Kenya, Morocco, and Zimbabwe.

In the same pattern, Nowbutsing \& Odit (2009) examined the influence of stock market development on economic growth in Mauritius using the Error Correction Approach on annualized data such as market capitalization, volume of trade and gross domestic product between 1989 and 2006. The result revealed that stock market development influence economic growth in the short run and long run. Also, Odhiambo (2010) examined relationship between stock market development and economic growth in South Africa using the Autoregressive Distributed Lag testing on annual data such as market capitalization, value of trade, market turnover and real GDP per capita between I97I and 2007. The results revealed a short and long run causal relationship between stock market performance and economic growth.

Likewise, Oskooe (2010) assessed the relationship between stock market performance and economic growth in Iran using Vector Error Correction model on quarterly time series data between 1997 and 2008. The results revealed a short and long run interaction between stock performance and economic growth in Iran as economic activities play an important feature in stock prices fluctuation in the long run. Mishra, Mishra, Mishra \& Mishra (2010) examined the influence of stock market efficiency on economic growth in India using multiple regression analysis on quarterly time series data such as market capitalization, market turnover and stock price index between I99I and 20I0. The result showed a nexus between stock market and economic growth.

A study by Koirala (20II) examined the impact of stock exchange on gross domestic product in United Kingdom using a multiple regression analysis and the finding disclosed that market capitalization ratio has positive effect on gross domestic product. Fynn (2012) examined the effect of the stock market on economic growth in selected countries using the Generalized Least Squares techniques on annual panel data between 2005 and 20I0. The result showed that the nature of stock market influence on growth is country and time specific. Wang and Ajit (2013) examined the influence of stock market development on economic growth in China using cointegration approach on quarterly data between 1996 and 20II. The result revealed that stock market development has a negative influence on economic growth as its activities are administrative-driven. Ikikii \& Nzomoi (2013) examined the influence of stock market development on economic growth in Kenya using multiple regression on quarterly data such as trade volume, market capitalization and economic growth between 2000 and 20II. The result revealed that stock market development has a positive influence on economic growth.

Similarly, Ishioro (2013) examined the causal linkage existing between stock market development and economic growth in Zimbabwe using the long-run non-causality technique on quarterly data such as market capitalization and GDP growth rate between 1990 and 2010. The results revealed a bi-directional relationship between economic growth and stock market development. Pan and Mishra (2016) examined the relationship between stock market development and economic growth in China using the Autoregressive Distributed Lag estimation technique and the results revealed that Global Financial Crises (GFC) had a substantial influence on various economic activities as stock market has a negative influence on the economy. Similarly, an evidence of a demand driven hypothesis was observed as economic growth influence stock market development.

In Nigeria, several studies have examined the nature of the interaction between stock market activities and economic growth but their measurement of variables and results yield mix reports. For instance, Kolapo \& Adaramola (2012) examined the influence of stock market on economic growth in Nigeria using Co-integration and Granger Causality test on annual data such as gross domestic product, market capitalization, total transactions and listed equities. The results showed that stock market activities have positive influence on economic growth.

Equally, Okodua \& Ewetan (2013) examined the influence of stock market performance and sustainable economic growth in Nigeria using the Autoregressive Distributed Lag estimation technique and the result revealed that economic growth is insignificant to stock market performance. Okoye \& Nwisienyi (2013) examined the influence of stock market on economic growth in Nigeria using multiple regression analysis on annual data such as all share index, market value, capitalisation and GDP between 2000 and 20I0. The result revealed that stock market has a significant influence on economic growth. Echekoba, Ezu and Egbunike (2013) examined the influence of stock market on economic growth in Nigeria using multivariate regression on 
annualized data such as all share index, market capitalisation and GDP between I999 and 20I I. The result revealed that market capitalization and all share index have positive influence on economic growth.

Equally, Jibril, Salihi, Wambai, Ibrahim, Muhammad \& Ahmad (2015) examined the influence of stock market development on economic growth in Nigeria using multiple correlation and regression analysis on annual data such as value of stock traded, market size, capitalisation and GDP between 1990 and 2010. The result showed that market capitalization and value of stock traded exact a negative influence on economic growth while turnover exacts a positive influence on economic growth. Afolabi (20I5) assessed the influence of stock market on the Nigerian economy using multiple regression analysis on annual data such as gross domestic product, market capitalization, foreign direct investment, inflation rates, new issues, transaction values and listed firms between 1992 and 20II. The result of the data analysis revealed an insignificant interaction between stock market and the Nigerian economy.

Popoola, Ejemeyovwi, Alefe, Adu \& Onabote (2017) examined the influence of stock market on and economic growth in Nigeria using the Error Correction Model on annualized data such as real gross domestic product, gross capital formation, market capitalization, all share index and value of transaction between I980 and 20I4. The result revealed that most of the selected measure exact a negative insignificant influence on economic growth.

\section{Methods and Materials}

The study obtained annual secondary data on stock market activities and economic growth in Nigeria from the Central Bank of Nigeria (CBN) Statistical Bulletin for the period between 1986 and 2017. The choice of this period coincides with the commencement of the Stock Market All Share Index computation in Nigeria. The study examined the influence of stock market activities on economic growth in Nigeria. The mathematical equation for estimating the relationship between stock market activities and economic growth is derived from the Efficient Market Hypothesis (EMH) which states that a financial market is efficient on prices of dealing financial assets as they are balanced and reflect all appropriate information as well as collective beliefs and preference of all market participants about the financial instruments' market prospect (Fama, 1970).

Copeland \& Weston (1979), observed that the EMH is not much restrictive than perfect stock market as market prices fully and instantaneously reflect all available information though it may not be realistic within the concept of asymmetric information. Thus, the measurement of market efficiency is contingent on the available information and varies according to nature of events in the stock market. The information can be in form of message $(m)$ having diverse values to different market participants as the potential desirable outcome from the information relative to the wealth maximization objective function and information can encourage decision making. Thus, the value $V(\eta)$ of information derived from the efficient stock market can be quantified as follows:

$$
V(\eta)=\sum_{m} q(m) M_{a} X \sum_{e} p(e / m) U(a, e)
$$

where,

$V(\eta) \quad=$ Value of the measured information $\eta$.

$q(m) \quad=$ the marginal probability of receiving message $\mathrm{m}$.

$p(e / m) \quad=$ the conditional probability of an event $€$ given a message $(\mathrm{m})$.

$U(a, e) \quad=$ the utility resulting from a decision (a)if an event (e) occurs.

This is referred to as a benefit function or payoff function which can be calibrated mathematically with the stock market activities as:

Statistically the equation is represented as:

$$
G D P=f(M C, N O D, V O T, A L S I)
$$

Where

$$
G D P_{T}=\lambda_{0}+\lambda_{1} M C_{t}+\lambda_{2} N O D_{t}+\lambda_{3} V O T_{t}+\lambda_{4} A L S I_{t}+\epsilon_{t}
$$

GDP $=$ Gross Domestic Product in Nigeria;

$\mathrm{MC}=$ Market Capitalization of the Stock Exchange

NOD $=$ Numbers of Deals

VOT $=$ Volume of Trade

ALSI $=$ All Share Index

However, due to the diverse nature of the selected components of the measures of stock market activities, it is imperative to take the logarithm of the model in order to bring the variables into identical base. Thus, the model becomes:

$$
\log G D P_{T}=\lambda_{0}+\lambda_{1} \log M C_{t}+\lambda_{2} \operatorname{LogNOD}_{t}+\lambda_{3} \operatorname{LogVOT}_{t}+\lambda_{4} \operatorname{LogALSI}_{t}+\epsilon_{t}
$$

Thus, equation (3) is the base line equation for this study.

\section{Estimation Procedure}




\section{Unit Root Test}

A major pre-test before a cointegration estimation is the unit root test, a stationary time series test which check if the mean and autocovariances of a series time independent. A simple model for nonstationary is the random walk.

$$
y_{t}=y_{t-1}+\epsilon_{t}
$$

$y$ is a constant forecast value conditional on $t$ with an increasing variance while $\epsilon$ is the stochastic term. A difference stationary series is integrated and symbolized as $\mathrm{I}(d)$ where $d$ is the order of integration which is the number of a series unit roots or number of differencing operations required to make the series stationary.

\section{Cointegration Test}

Having established the unit root test of all the variables employed, the study test for cointegration using the VAR-based approach developed by Johansen (I99I). This cointegration test was designed using a group object based on a VAR of order $\mathrm{p}$ :

Where:

$$
y_{t}=A_{1} y_{t-1}+\cdots+A_{p} y_{t-p}+B x_{t}+\epsilon_{t}
$$

$y_{t}$ represents k-vector of non-stationary $\mathrm{I}(\mathrm{I})$ variables,

$x_{t}$ represents $\mathrm{d}$-vector of deterministic variables, and

$\epsilon_{t}$ represents vector of innovations. This model can be modified as:

$$
\Delta y_{t}=\Pi y_{t-1}+\sum_{i-1}^{p-1} \Gamma_{i} \Delta y_{t-i}+B x_{i}+\epsilon_{i}
$$

Where:

$$
\Pi=\sum_{i=1}^{p} A_{i}-I, \quad \Gamma_{i}=-\sum_{j=i+1}^{p} A_{j}
$$

Granger's representation theorem states that if the coefficient matrix $\Pi$ has reduced rank such that $r$ is less than $k$, then there exist $k x r$ matrices $\alpha$ and $\beta$ each with a rank of $r$ such that $\Pi$ is equal to $\alpha \beta^{\prime}$ while $\beta^{\prime} y_{t}$ is $\mathrm{I}(0)$. $r$ represents the number of cointegrating relations and each column of $\beta$ represents the cointegrating vector. Also, the elements of $\alpha s$ are the Error Correction Model adjustment parameters. The Johansen's method estimates the $\Pi$ matrix from an unrestricted VAR and test if the restrictions created by the reduced rank of $\Pi$.

\section{ECM Regression}

Based on the results of the unit root and cointegration tests, the study estimate the ECM regression associated with Autoregressive Distributed Lag (ARDL) derived through the lagged levels and first difference of $y_{t}, x_{1 t}, x_{2 t}, \ldots, x_{k t}$, and $w_{t}$.

$$
\phi(L, p) y_{t}=\sum_{i=1}^{k} \beta_{i}\left(L, q_{i}\right) x_{i t}+\delta^{\prime} w_{t}+\mu_{t}
$$

Where $L$ represent a lag operator such that $L y_{t}=y_{t-1}$

$w_{t}$ is a s $\mathrm{I}$ vector of deterministic variables such as the intercept term, seasonal dummies or (time trends, or exogenous variables with fixed lags.

The model is linked thus:

$y_{t}=\Delta y_{t}+y_{t-1}(9)$

$$
\begin{array}{cc}
y_{t-s}=y_{t-1}-\sum_{j=1}^{s-1} \Delta y_{t-j,} & s=1,2, \ldots, q_{i} \\
w_{t}=\Delta w_{t}+w_{t-1} & \\
x_{i t}=\Delta x_{i t}+x_{i, t-1} & s=1,2, \ldots, q_{i} \\
x_{i, t-s}=x_{t-s}-\sum_{j=1}^{s-1} \Delta x_{i, t-j,} &
\end{array}
$$

Substituting equations 8-I2 into equation 7 and simplify further, the model gives equation I4 thus: 
$\Delta y_{t}=-\phi(1, p) E C_{t-1}+\sum_{i=1}^{k} \beta_{i 0} \Delta x_{i t}+\delta^{\prime} \Delta \mathrm{w}_{t}-\sum_{j=1}^{p-1} \phi_{j}^{*} \Delta y_{t-j}-\sum_{i=1}^{k} \sum_{j=1}^{q i-1} \beta_{i j}^{*} \Delta x_{i, t-j}+u_{t}$

where $E C_{t}$ is the correction term defined as

5. Results and Discussions

$$
E C_{t}=y_{t}-\sum_{i=1}^{k} \hat{\theta}_{i} x_{i t}-\psi^{\prime} w_{t}
$$

Table I. Augmented Dickey-Fuller test statistic for the variables

\begin{tabular}{lccccc}
\hline \multicolumn{4}{c}{ Level } & \multicolumn{2}{c}{ First Difference } \\
\hline & Statistic & Prob. & Statistic & Prob. & Interpretation \\
\hline LogGDP & I.I53462 & 0.9999 & -4.137249 & $0.0 \mathrm{I} 4 \mathrm{I}^{*}$ & $\mathrm{I}(\mathrm{I})$ \\
\hline LogMC & -0.540636 & 0.9759 & $-4.43553 \mathrm{I}$ & $0.0070^{* *}$ & $\mathrm{I}(\mathrm{I})$ \\
\hline LogNOD & $-\mathrm{I} .049364$ & $0.922 \mathrm{I}$ & -5.727334 & $0.0003^{\text {* }}$ & $\mathrm{I}(\mathrm{I})$ \\
\hline LogVOT & $-\mathrm{I} .156397$ & 0.9026 & -4.198723 & $0.0126^{*}$ & $\mathrm{I}(\mathrm{I})$ \\
\hline LogALSI & -0.649602 & 0.9685 & -4.878740 & $0.0037^{*}$ & $\mathrm{I}(\mathrm{I})$ \\
\hline
\end{tabular}

* Significant at $5 \%$ level of significance

Source: (Authors' Computation, 2018)

Table I presents the results of Augmented Dickey-Fuller test statistics for all the variables at level and first differences. The ADF test allows for heterogeneous coefficients with a null hypothesis that the specified variables follow a unit root process and to reject this, the ADF probability value must be less than or equal to 0.05. The ADF test revealed that all variables are $\mathrm{I}(\mathrm{I})$ and stationary at first difference. Based on the result, this study proceed to the cointegration test and the result is presented in table 2.

Table 2. Trace and Maximum Eigenvalue Cointegration Rank Test Results

\begin{tabular}{ccccc}
\hline $\begin{array}{c}\text { Hypothesized } \\
\text { No. of CE }(\mathbf{s})\end{array}$ & $\begin{array}{c}\text { Trace test } \\
\text { Statistics }\end{array}$ & Prob. & $\begin{array}{c}\text { Max-Eigen } \\
\text { Statistics }\end{array}$ & Prob. \\
\hline None & 174.08 & $0.0000^{\text {** }}$ & 94.7510 & $0.0000^{\text {** }}$ \\
\hline At most I & 79.3322 & $0.0000^{\text {** }}$ & 34.6936 & $0.0052^{\text {** }}$ \\
\hline At most 2 & 44.6386 & $0.0005^{\text {** }}$ & 21.0466 & 0.0514 \\
\hline At most 3 & 23.5920 & $0.0024^{\text {** }}$ & 13.4536 & 0.0669 \\
\hline At most 4 & I0.1383 & $0.0015^{\text {** }}$ & 10.1383 & $0.0015^{\text {* }}$ \\
\hline
\end{tabular}

Significant at $5 \%$ level of significance

Source: (Authors' Computation, 2018)

Table 2 revealed that the Trace test statistics established four (4) cointegrating equations while the Max-Eigen statistics established two (2) cointegrating equations. This implies that a cointegrating relationship exist among the specified variables and create the basis for the computation of the ECM. The result of the ECM is represented in Table 3.

Table 3. Error Correction Model Result

\begin{tabular}{|c|c|c|c|c|}
\hline \multicolumn{5}{|c|}{ Dependent Variable: dLogGDP } \\
\hline Variable & Coefficient & Std. Error & T-Ratio & Prob. \\
\hline $\mathrm{dLogMC}$ & 0.0386 & .04116 & .93886 & 0.356 \\
\hline dLogNOD & 0.0487 & 0.0270 & I.803I & 0.083 \\
\hline dLogVOT & $-0.06 \mathrm{II}$ & 0.0315 & -1.9386 & 0.063 \\
\hline dLogALSI & 0.0921 & $0.030 \mathrm{I}$ & 3.0568 & 0.005 \\
\hline $\operatorname{ECM}(-\mathrm{I})$ & -0.0955 & 0.0434 & -2.2004 & 0.037 \\
\hline R-squared & 0.5157 & \multicolumn{2}{|c|}{ Mean dependent var } & 0.0845 \\
\hline Adjusted R-squared & 0.4439 & \multicolumn{2}{|c|}{ S.D. dependent var } & 0.0488 \\
\hline S.E. of regression & 0.0364 & \multicolumn{2}{|c|}{ Sum squared resid } & 0.0358 \\
\hline Equation Log-likelihood & 63.3355 & \multicolumn{2}{|c|}{ Akaike Info. Criterion } & 58.3355 \\
\hline F-Stat. F $(4,27)$ & $7.1873(0.00)$ & \multicolumn{2}{|c|}{ Schwarz Bayesian Criterion } & $54.67 \mathrm{I} 2$ \\
\hline Durbin-Watson stat & $\mathrm{I} .8 \mathrm{I05}$ & & & \\
\hline
\end{tabular}


* Significant at $5 \%$ level of significance

Source: (Authors' Computation, 2018)

Table 3 shows the ECM result coefficients, standard error, t-statistics and probability values for all the specified model. The result reveals the influence of each explanatory variable on economic growth in Nigeria. The ECM result $(-0.0955, p<0.05)$ is statistically sign and significant which implies that the speed of adjustment to equilibrium is $9.55 \%$ and offset are adjusted in each period. The stock market activities measurement such as market capitalization $\left(\lambda_{1}=0.0386, p>0.05\right)$, number of deals $\left(\lambda_{2}=\right.$ 0.0487, $p<0.05)$ and All Share Index $\left(\lambda_{4}=0.092 \mathrm{I}, p<0.05\right)$ have positive influence on economic growth, while the volume of trading $\left(\lambda_{3}=-0.6110, p<0.05\right)$ has a negative effect on economic growth. Similarly, the coefficient of determination $\left(\mathrm{R}^{2}\right)$ value of 0.5157 implies that stock market activities can explain about 51.57\% variation in economic growth in Nigeria while the FStatistic value indicates that all the estimated coefficients are statistically different from zero at 5\% level of significance. These results suggested that all the specified variables except market capitalization have significant effect on economic growth in Nigeria within the period investigated.

\section{Conclusion and Recommendation}

This study examined the influence of stock market activities on economic growth in Nigeria and the results showed a statistically sign and significant ECM with measures such as number of deals, All Share Index and volume of trading have a significant influence on economic growth in Nigeria. This implies that the number of deals and All Share Index are the main indicator of stock market activities in Nigeria that influence economic growth positively within the period while the volume of trading exacts a negative influence due to transaction costs and its ancillary. Similarly, the study revealed that market capitalization has a positive influence on economic growth, though the extent of the influence is not significant. The study recommend that investors should take the advantage of the various opportunities offered by the stock market in Nigeria while market makers and regulators should continue to operate according to acceptable best market practices and global standards in order to ensure increased confidence and continuous patronage by various economic agents.

\section{References}

Afolabi, A. A. (2015). Impact of the Nigerian capital market on the economy, European Journal of Accounting Auditing and Finance Research, 3(2), 88-96.

Beck, T. \& Levine, R. (200I). Stock Markets, Banks, and Growth: Correlation or Causality? Policy Research Working Paper 2670, Washington DC: World Bank.

Bencivenga, V. R., Smith, B. \& Starr, M. (I996). Equity Markets, Transaction costs, and Capital Accumulation: An illustration. World Bank Economic Review, I0, 643- 65.

Copeland, T. E. \& Weston J. F. (I979). Financial Theory and Corporate Policy, 3, 32-26.

Echekoba, F. N., Ezu, G. K. \& Egbunike, C. F. (2013). The impact of capital market on the growth of the Nigerian economy under democratic rule, Arabian Journal of Business and Management Review, 3(2), 53-62.

Enisan, A. \& Olufisayo, A.O.(2009). Stock market development and economic growth: evidence from seven Sub-Sahara African Countries. Journal of Economics and Business, $6 \mathrm{I}(2)$.

Fama, E.F. (1970). The behaviour of stock market prices, Journal of Business, 39(I), 3I-65.

Fynn, K. D. (2012). Does the equity market affect economic growth? Macalester Review Journal, 2(2), I-I2.

Ikikii, S. M. \& Nzomoi, J. N. (20I3). An analysis of the effects of stock market development on economic growth in Kenya, International Journal of Economics and Finance, 5(I I), I45-I55.

Ishioro O. B. (2013). Stock market development and economic growth: evidence from Zimbabwe. Ekon. Misao praksa dbk

Jibril, S. R., Salihi, A. A., Wambai, U. S., Ibrahim, F. B., Muhammad, S. and Ahmad, T. H. (2015). An assessment of Nigerian stock exchange market development to economic growth, American International Journal of Social Science, 4(2), 5I58.

Johansen, S. (I99I). Estimation and hypothesis testing for cointegration vectors in Gaussian Vector Autoregressive Models. Econometrica, 59, I55 I-I580.

Koirala, J. (20II). The effect of stock market development on economic growth: an empirical analysis of UK, Electronic copy available at: http://ssrn.com/abstract $=2494640$

Kolapo, F. T. \& Adaramola, A. O. (2012). The impact of the Nigerian capital market on economic growth (I990-2010), International Journal of Developing Societies, I(I), I I-I9.

Mishra, P.K., U.S., Mishra, U.S., Mishra, B.R., \& Mishra. P. (20I0). Capital market efficiency and economic growth: The case of India. European Journal of Economics, Finance and Administrative Sciences Issue ,27 (I8), I30-I38.

Nowbutsing, B. M. \& Odit, P. M. (2009). Stock Market Development and Economic Growth:The Case of Mauritius, International Business and Economics Research Journal, 8(2), 77- 88. 
Odhiambo, N.M. (2010). Stock market development and economic growth in South Africa: An ARDI Bounds. Department of Economics, University of South Africa.

Okodua, H., \& Ewetan, O. O. (2013). Stock market performance and sustainable economic growth in Nigeria: A bounds testing co-integration approach. Journal of Sustainable Development, 6(8).

Okoye, V. O. \& Nwisienyi, K. J. (2013). The capital market contributions towards economic growth and development: the Nigerian experience, Global Advanced Research Journal of Management and Business Studies, 2(2), I20-I25.

Osei, V. (2005). Does the stock market in Ghana? A granger causality analysis bank of Ghana Working Paper ,05(I3).

Oskooe, S.A.P. (2010). Emerging stock market performance and economic growth. School of Economics, Kingston University. American Journal of Applied Sciences, 7(2), 265-269.

Pan L. \& Mishra V. (2016). Stock Market Development and Economic Growth: Empirical Evidence from China. Department of Economics Discussion Paper I6/16, ISSN I44I- 5429, Monash Business School.

Popoola, O. (20I4). The effect of stock market on Nigerian economy. Unpublished Manuscript, Department of Economics, Landmark University, Kwara State, Nigeria.

Popoola O.R, Ejemeyovwi O. J, Alege, O.P., Adu O., \& Onabote A. A. (2017). Stock market and economic growth in Nigeria. International Journal of English Literature and Social Sciences, 2(6), 97-106

Wang, B. \& Ajit D. (2013). Stock Market and Economic Growth in China. Economic Bulletin, Access Econ, 33(I), 95-I03.

\section{Copyrights}

Copyright for this article is retained by the author(s), with first publication rights granted to the journal.

This is an open-access article distributed under the terms and conditions of the Creative Commons Attribution license

(http://creativecommons.org/licenses/by/4.0/) 